\title{
BIBLIOGRAPHICAL RECORD OF CONTENTS OF VOLUME FOUR OF PSYCHE.
}

Academy of natural sciences of Philadelphia. (Psyche, Mch.-Apr. I883, v. 4, p. 32, I7 cm.)

Abstract of entomological communications made at meetings of Academy, etc., from 8 Aug. 1882 to $23 \mathrm{Jan}$. $188_{3}$, compiled from "Proceedings of the Philadelphia academy of sciences [25 Jul. 1882-6 Feb. 1883]" (Amer. nat., A pr. 1883, v. 17, p. 462-466). B: P. $M$. (4058)

Advertisements. (Psyche, I883-ı 885, v. 4, p. $2,22,42,62,82$, IO2, I 22, I 42 , I $5+, 166$, I 78, I94, 21 4, 238, 270, 302, 330.)

For further record, see names of respective advertisers.

$B: P . M$. (4059)

American agriculturist. (Psyche, I884I 885, v. 4 , p. I94, 2 I $4,238,270,302$, each $5 \mathrm{~cm}$.)

Advertisement. B: P. M. (4060)

[Anal appendages of lepidoptera.] (Psyche, May-June $\mathrm{I} 883$, v. 4 , p. $59,8 \mathrm{~cm}$.)

References to numerous accounts of the discovery of anal appendages in lepidoptera.

$B: P . M .(406 \mathrm{r})$

Anatomy of macrotoma plumbea. (Psyche,

Oct.-Dec. 1885, v. 4 , p. $354,13 \mathrm{~cm}$.)

Translation, from Entom. nachrichten, Jul. I885, v. 11, p. 221-222, of abstract of A. Sommer's "Ueber macrotoma plumbea. Beiträge zur anatomie der poduriden" (Zeitschr. für wiss. zool., 1885, v. 4I, p. 683-718); histology of egg and of ventral tube; frequent molting of imago; occurrence of parasites; synonymy. $B: P . M .(4062)$

[Anderson, Joseph, jr.] Posture of newly emerged butterflies. (Psyche, Oct.-Dec. $\mathrm{I} 88_{5}$, v. $4, \mathrm{p} .35^{2}, 7 \mathrm{~cm}$.)

Notice of Joseph Anderson, jr.'s "Habits of vanes. sidae on emergence" (Entomologist, Sept. 1885 , v. 18 , p. $\left.24 \mathrm{I}-24^{2}\right)$, and of other papers by him.

B: P. M. (4063)

Angus, James. Protective change of color in a spider. (Psyche, Jan.-Feb. I883, v. 4, p. $19-20,7 \mathrm{~cm}$.)

Reprint from American naturalist, Dec. 1882, v. 16, p. Ioro; a white spider, placed on a yellow flower, became yellow; capture of insects by such a spider. $B: P$. $M$. (4064)

Aphis nectar and honey. (Psyche, Apr.June 1885 , v. 4 , p. 300 , Io cm.)

Reprint of "[Nectar secretion from aphides]" (Science, 23 Jan. 1885, v. 5, p. 82); abundance and quality of nectar secreted by aphididae; production of honey from this nectar by apis mellifica.

B: P. M. (4065)
[Apgar, Austin C.] [Naphthalin vs. anthrenus.] (Psyche, Oct.-Dec. I884, v. 4, p. $234,5 \mathrm{~cm}$.)

Notice, extracted from Science, 21 Nov. 1884, v. 4, Bulletin, p. 5, of communication made by A. C. Apgar, I I Nov. I884, to Trenton natural history society; resistance of anthrenus scrophulariae to the effects of vapor of naphthalin.

B: P. M. (4066)

[Aquatic coleoptera living in poisonous solutions.] (Amer. nat., Aug. I883, v. I7, p. 903-904.) (Psyche, Jul.-Aug. I $88_{3}$, v. 4, p. $79,7 \mathrm{~cm}$.

Survival of aquatic coleoptera for long periods in aqueous solutions of curare and strychnine.

$$
\text { B: P. M. (4067) }
$$

[Aubert, -, and Dubois, Raph.] [Luminosity of pyrophorus.] (Science, 28 Nov. I 884, v. 4, p. 505.) (Psyche, Oct.-Dec. $\mathrm{r} 884$, v. 4 , p. $234,4 \mathrm{~cm}$.)

Notice of Aubert and R. Dubois' "Sur les propriétés de la lumière des pyrophores" (Compt.-rend. Acad. sci. [Paris], I5 Sep. 1884, v. 99, p. 477-479); character of spectrum of light emitted by pyrophorus.

B: P. M. (4068)

[Audolent, P.] Tenacity of life in calliphora vomitoria. (Psyche, Oct.-Dec. 1885 , v. 4, p. $35 \mathrm{I}, 4 \mathrm{~cm}$.)

Larvae of calliphora vomitoria survived for two days under water, and pupated there. $B: P$. $M$. (4069)

[Aurivillius, Christopher.] Lycaenid larvae in ants' nests. (Psyche, Apr.-June r 885, v. 4, p. 299-300, IO cm.)

Notice translated from Entomologisk tidskrift, 1884, p. 227, of communication made by $\mathbf{C}$. Aurivillius to Entomologisk förening i Stockholm, r Oct. 1884. B: P. M. (4070)

Barnard, W: Stebbins. Treatment processes against phylloxera vitifoliae. (Psyche, Mch. I884, v. 3, p. $143-144,65 \mathrm{~cm}$.)

Remarks upon the efficacy of the nether-insertion process devised by the writer as a means against phylloxera vitifoliae and other subterranean insects, and upon the use of petroleum emulsions, also devised by the writer, as a means against noxious insects in general. B: P.M. (4071)

Barrett, C : Golding. Effect of cyanide upon colour. (Psyche, Aug.-Sep. r884, v. 4, p. 204, 9 cm.)

Reprint of author's "Effect of cyanide upon colour" (Entom. mo. mag., June I884, v. 21, p. 23). B: P. M. (4072) 
Biological society of Washington. (Psyche, Jan.-Feb. I 884 , v. 4, p. I 33-I 34, 39 cm.)

Partial abstract of communications made at meetings of Biological society of Washington, 14 Dec. and 28 Dec. 1883 . $B: P . M$. (4073)

[Books on spiders.] (Science, 23 Mch. 1883 , v. I, p. 207.) (Psyche, Mch.-Apr. I883, v. 4, p. 39,2 cin.)

Announcement of forthcoming works on spiders by H: C. McCook.

$B: P . M .(4074)$

Brauer, Friedrich. The larvae of oestridae. (Psyche, Jul.-Sep. I885, v. 4, p. 305-310, I $85 \mathrm{~cm}$.)

Translation, by B: P. Mann, of portion of F. Brauer's "Monographie der oestriden," Wien, I863, p. $35-40$, treating generally of the structural characters, molts and life-habits of larvae of oestridae, and of the affinities of the genera.

B: P. M. (4075)

[Brongniart, C:] Fossil thysanura. (Psyche, Oct.-Dec. 1885 , v. 4 , p. 353 , I5 cm.)

Translation of C: Brongniart's " Dasyleptus lucasi, sp. n. foss.]" (Bull. Soc. entom. France, 1885, Bull. d. séances, p. 101-102); description of fossil thysanura (dasyleplus lucasi) occurring in the carboniferous schists of Commentry.
cocurring in the carboniferous
B. $M$. (4076)

Bullettino del naturalista collectore. (Psyche, I884, v. 4, p. 142, I 54, 166, I 70, 194, each $3 \mathrm{~cm}$.)

Advertisement.

B: P. M. (4077)

Cambridge entomological club. (Psyche, Jan.-Feb. I 883 , v. 4, p. I3-14, 59 cm.)

Minutes of annual and monthly meeting of Cam. bridge entomological club, i2 Jan. I 883 , and of monthly meeting, 9 Feb. IS83 [by the secretary (G: Dimmock)]; election of officers for 1883 ; election of members; arrangements for publication of volume four of PSYCHE; abstract of communications made. B: P. M. (4078)

Cambridge entomological club. (Psyche, May-June 1883, v. 4 , p. $54,8 \mathrm{~cm}$.)

Minutes of monthly meeting of Cambridge entomological club, 9 March 1883 [by the secretary (G: Dimmock)]; abstract of communications made.

$$
\text { B: P. M. (4079) }
$$

Cambridge entomological club. (Psyche, Nov.-Dec. 1883 , v. 4, p. I I6, Io cm.)

Minutes of monthly meetings of Cambridge entomological club, '3 Apr. 1883 [by the secretary (G: Dimmock)]; abstract of communications made.

$$
\text { B:P. M. (4080) }
$$

Cambridge entomological club. (Psyche, Jan.-Feb. I 884, v. 4, p. I33, $20 \mathrm{~cm}$.)

Minutes of montinly meeting of Cambridge entomological club, i I May $188_{3}$ [by the secretary (G: Dim. mock)] ; abstract of communications made.

$$
\text { B: P. M. (4081) }
$$

Cambridge entomological club. (Psyche, Mch. I884, v. 4, p. I 47 , I 4 cm.)

Minutes of monthly meeting of Cambridge entomological club, 8 June 1883 [by the secretary (G: Dim. mock)]; abstract of communications made.

$$
\text { B: P. M. (4082) }
$$

Cambridge entomological club. (Psyche' Apr. I884, v. 4, p. I60, 27 cm.)

Minutes of monthly meeting of Cambridge entomo. logical club, 12 Oct. and 9 Nov. and in part of monthly meeting, 14 Dec. 1883 [by the secretary (G:Dimmock)]; withdrawal of members; abstract of communications made.

B: P. M. (4083)

Cambridge entomological club. (Psyche, May I 884, v. 4 , p. I70, $27 \mathrm{~cm}$.)

Minutes of monthly meeting of Cambridge entomo. logical club, 14 Dec. 1883 (concluded), and in part of annual and monthly meeting, i I Jan. 1884 [by the secretary (G: Dimmock)] ; abstract of communications made; election of officers for 1884 ; election and withdrawal of members. B: P. M. (4084)

Cambridge entomological club. (Psyche, Jun.-Jul. 1884 , v. 4 , p. 186,34 cm.)

Minutes of annual and monthly meeting of Cam. bridge entomological club, iI Jan. I884 (concluded), and of monthly meeting, 8 Feb. 1884 [by the secretary (G: Dimmock)]; abstract of annual reports for 1883 , and of communications made; acceptance and withdrawal of members. $B: P . M .(4085)$

Cambridge entomological club. (Psyche,

Oct.-Dec. I 884 , v. 4, p. 224-226, 70 cm.)

Minutes of monthly meetings of Cambridge entomo. logical club, March-June and Oct.-Dec. 1884 by the secretary (G: Dimmock)]; withdrawals and death of members; abstract of communications made. B: P. M. (4086)

Cambridge entomological club. (Psyche, Oct.-Dec. I 885 , v. 4 , p. $335-338$, I 6 cm.)

Minutes of annual and monthly meeting of Cambridge entomological club, $5 \mathrm{Jan}$. $\mathrm{J} 885$, and of monthly meetings, Feb..June and Oct.-Dec. 1885 [by the secretary (G: Dimmock) ]; abstract of secretary's (G: Dimmock) and treasurer's (B:P. Mann) reports for 1884 , and of communications made; withdrawal of a member; vote of thanks to S: H. Scudder for the use of the office of Science for club meetings.

B: P. M. (4087)

[Carbon disulphide poisonous.] (Psyche, Apr. I 884, v. 4, p. 163,4 cm.)

Translation, from Deutsch-amerikanische apothekerzeitung, 15 Feb. 1884 , v. 4 , p. 736 , of statement that the continued breathing of the vapor of carbon disulphide $\left[\mathrm{CS}_{2}\right]$ produces mental derangement. $B: P . M .(4088)$

[Carlet, Gaston.] [Poison-glands of hymenoptera.] (Amer. nat., Dec. r884, v. I8, p. 1270.) (Psyche, Oct.-Dec. I884, v. 4 , p. $235,7 \mathrm{~cm}$.)

Abstract of G. Carlet's "Sur le venin des hyméno. ptères" .... (Compt.-rend. Acad. sci. [Paris], 23 June 1884 , v. 98, p. ${ }_{55}$ O-155 I) [Rec., 3685].

B: P. M. (4089)

[Caterpillars in Sweden.] (Nature, 5 Jul. I883, v. 28, p. 234.) (Psyche, Jul.-Aug. I883, v. 4 , p. 79,4 cm.)

Occurrence of unknown injurious lepidopterous larva in several parts of Sweden, in 1883 .

B̈: P. M. (4090) 
Chambers, Vactor 'Tousey. The classification of the tineidae. (Psyche, Jul.-Aug. I 883, v. $4, \mathrm{p} .7 \mathrm{I}-74, \operatorname{IOg} \mathrm{cm}$.

Comments upon remarks made in A : R. Grote's "A brief essay on classification of the heterocera" (Papilio, Feb. 1883 , v. 3, p. 35-38); anaphora undoubtedly a tineid, even in a restricted sense, but differing more from many so-called tineids in a broad sense than from noctuidae, the so-called tineidae in a broad sense very heterogenecus, and equivalent to the union of many families recognized as distinct; indication of several diverse groups of genera.

$B: P . M$. (4091)

Chevrolat's collection of coleoptera. (Psyche, Apr.-June i 885, v. 4, p. 297, $5 \mathrm{~cm}$.)

Notice of offer for sale of A. Chevrolat's collection of coleoptera, and of some prices asked.

B: P. M. (4092)

Chigoe ('The) in Africa. (Amer. nat., June I883, v. I7, p. 664.) (Psyche, May-June I 883 , v. 4 , p. $52,6 \mathrm{~cm}$.)

Pulex penetrans stated, in Burton and Cameron's "To the Gold coast for gold," to have been introduced and widely spread recently in western Africa; mention ot some of the chief arthropodous plagues of that region

B: P. M. (4093)

Comstock, J : H : Coccidae wanted. (Psyche, v. 4, 1883, p. 2, 22, 42, 62, 82, 102; 1884, p. I 22, I42, I54, I66, each $4 \mathrm{~cm}$.)

Advertisement.

B: P. M. (4094)

[Cook, Albert J:] [Extra-floral nectar.] (Psyche, Oct.-Dec. I 884, v. 4, p. 234, 4 cm.)

Notice of paper read by A. J: Cook betore Natural history society of the Michigan agricultural college, 12 Sep. 1884; contrast of taste of honey made from secretion due to ergot on grass and of that made from secre. tion due to ergot on grass and of that made from secre-
tions of aphididae.
$B: P . M$. (4095)

Coquillett, Daniel W: Systematic position of the genus apiocera. (Psyche, Jan.-Mch. I 885 , v. 4 , p. $243-244,49$ cm.)

Critical review of C: R. Osten Sacken's "On the genus apiocera" (Berliner entom. zeitschr., 1883, v. 27, p. 287-294); reasons for placing apiocera among the therevilae rather than among the asilidae; characters of asilidae and therevidae compared; probable variability of apiocera haruspex.

$B: P . M .(4096)$

Dahl, Friedrich. Habits of spiders. (Psyche, Apr.-June I 885 , v. 4, p. $300, \mathrm{I} 6 \mathrm{~cm}$.)

Extract from partial translation, entitled "Contribu. tions to the biology of spiders" (Ann. and mag. nat. hist., Jan. I885, s. 5, v. 15, p. 70-72) [Rec., 3826], of author's "Beiträge zur biologie der spinnen" (Zool. anzeiger, 3 Nov. $188_{4}$, v. 7 , p. 591-595) [Rec., 3825]; notes on the repair of their webs by $z$ llla $x-n o t a t a$ and other araneina, and on the exhibition of intelligence and instinct by attus arcuatus.

B: P. M. (4097)

Data on annual addresses. (Psyche, Jan.Mch. $188_{5}$, v. 4 , p. 265,9 cm.)

List of annual addresses of retirng presidents of Cambridge entomological club. $\quad B: P . M .(4098)$
[Davison, W:] Birds nesting in hornets' nests. (Psyche, Oct.-Dec. I 885 , v. 4, p. $35 \mathrm{I}, 4 \mathrm{~cm}$.)

Extract from W: Davison's "Birds breeding in ants' nests" (Nature, 12 Mch. I885, v. 31, p. 438).

$$
\text { B: P. M. (4099) }
$$

[Davis, W: 'T.] [Stridulation of a headless conocephalus. (Science, 7 Nov. I884, v. 4, p. 448, 4 cm.) (Psyche, Oct.-Dec. I 884 , v. 4 , p. $235,6 \mathrm{~cm}$.)

Notice of communication made by $W$ : T. Davis to Natural science association of Staten Island, Oct. I884.

$$
B: P . M . \text { (4100) }
$$

Dimmock, Anna Katherina. The insects of betula in North America. (Psyche, I885, v. 4: Jan.-Mch., p. 239-243, I42 cm.; Apr.Jun., p. 27 r-286, 507 cm.)

List of 107 determined species of insects and of some doubtful ones found on betula in North America, with references to the original descriptions and to other important descriptions or accounts of the life-histories of these insects, and with authenticated lists of the other food-plants of the species cited: use of leaves of betula alba in rearing polyphagous insects.

$$
\text { B: P. M. (4101) }
$$

Dimmock, Anna Katherina. Sexual attraction in prionus. (Psyche, Apr. I884, v. 4, p. $159,27 \mathrm{~cm}$.)

Abstract, with remarks [by $F$. Katter], entitled, "Geschlechtliche anziehung bei coleopteren." (Entom. nachrichten, June I 884, v. ro, p. I83-I86.)

Record of observations $n$ the attraction of males of prionus by females, and of females hy males.

$$
\text { B: P. M. (4102) }
$$

Dimmock, G:, secretary, see CAMBRIDGe entomological club.

Dimmock, G : [Blissus leucopterus.] (Psyche, Nov.-Dec. I883, v. 4, p. I19, $5 \mathrm{~cm}$.)

Notice of J. A. Lintner's Circular no. I of the Department of entomology of the New York state museum of natural history, Oct. $18 \mathrm{~S}_{3}$; occurrence of blissus leuco. pterus in New York and Massachusetts, in 1883.

$$
B: P . \dot{M} \text {. (4103) }
$$

Dimmock, G: [Book-notice.] (Psyche, May-June 1883 , v. 4 , p. 53-54, 9 cm.)

Notice of Proceedings of the Davenport academy of natural sciences, v. 3 , pt. 3. $\quad B: P . M$. (4104)

Dimmock, G : [Book notice.] (Psyche, May-June $\mathrm{I} 883$, v. 4 , p. 54,3 cm.)

Notice of Rovaraszati lapok, a Hungarian entomo. logical journal. $B: P . M .(4105)$

Dimmock, G: [Dollfus prize in insect anatomy.] (Psyche, May I884, v. 4, p. I $75,7 \mathrm{~cm}$.)

Notice of offer of prizes to subscribers to Feuille des jeunes naturalistes for illustrated anatomical work on the larva of a rhopalocerous lepidopteron. [For notice of award of prize, see G : Dimmock's note [of same title] (op. cit., Oct.-Dec, 1884, p. 234-235) (Rec. 4107). $]$ B: P. M. (4106) 
Dimmock, G: [Dollfus prize in insect anatomy.] (Psyche, Oct.-Dec. I884, v. 4, p. $234^{-2} 35,5 \mathrm{~cm}$.)

Notice of award of prizes offered by A. Dollfus for work on the anatomy of a lepidopterous larva, and of publication of the prize essays in Feuille des jeunes naturalistes in $\mathrm{I} 884$.

$B: P . M .(4107)$

Dimmock, G : [Index to Ontario entomological reports.] (Psyche, Jul.-Aug. 1883, v. 4, p. $79,6 \mathrm{~cm}$.)

Crit. rev. of E. B. Reed's "General index to the thirteen annual reports of the Entomological society of the province of Ontario, $1870-1882$," Toronto, I883.

B: $P . M . M(4108)$

Dimmock, G : [Leuckart as an educator.]

(Psyche, Mch. I884, v. 4, p. I52.)

Notice of biographical sketch of Prof. R. Leuckart by O. P. Krancher in Deutscher bienenfreund, Jan. 1884 . B. P. M. (4109)

[Dimmock, G:] Metamorphoses of arctic insects. (Psyche, Jan.-Mch. I885, v. 4, p. $268,32 \mathrm{~cm}$.)

Translated extract from C. Aurivillius' “ Das insektenleben in arktischen ländern" in A. E. Nordenskiöld's "Studien und forschungen ... im hohen norden," $L p z$. 1885 ; periods of time requisite for the development of oeneis bore, and presumably of bombus and other insects in high northern latitudes; absence of parasites of bombus in these regions. $\quad B: P . M$. (4110)

Dimmock, G: [Müller-fund.] (Psyche, Jan.-Feb. 1884 , v. 4, p. $139-140,7 \mathrm{~cm}$.)

Statement of plan and object of fund proposed to be raised in honor of Hermann Miiller. $B: P . M$. (4III)

Dimmock, G: Necrology. (Psyche, Jan.Mch. I 885 , v. 4, p. 266 , I5 cm.)

List of entomologists recently deceased, with dates of birth and death and with characterization of some of them.

$B: P . M .(4112)$

Dimmock, G: New text-book of entomology, (Psyche, Apr.-June I885, v. 4, p. 299, $10 \mathrm{~cm}$.)

Prospectus of "An elementary text-book of entomo. logy," to be published in London, with plates by $W: F$. Kirby.

$B: P, M$. (4113)

Dimmock, G : Notice to subscribers. (Psyche, Jan.-Feb. I883, v. 4, p. 20, 6 cm.) Notice of delay of completion of publication of volume three of PSYCHE. $B: P . M$. (4I 14$)$

Dimmock, G : [Obituary notice of Hermann Müller.] (Psyche, Sep.-Oct. I883, v. 4, p. $100,9 \mathrm{~cm}$.)

Reference to number and value of Müller's writings. $B: P . M .(4115)$

Dimmock, G: [Papilio cresphontes in Massachusetts.] (Psyche, Sep.-Oct. I883, v. 4 , p. $99,5 \mathrm{~cm}$.)

Record of captures of papilio cresphontes and of a capture of junonia coenia in Massachusetts, in ${ }_{1} 88_{3}$. B: P. M. $(4116)$
Dimmock, G: [Pieris spilleri Spiller.] (Psyche, Apr. I884, v. 4, p. I63-164, $5 \mathrm{~cm}$. ) Reprint. (Sci. record, I5 July I 884 , v. 2, p. 2 ro, $6 \mathrm{~cm}$.)

Notice of A. J. Spiller's "Description of a pieris new to science. Pieris spilleri, mihi" (Entomologist, Mch. 1884 , v. i 7, p. 62-63), commenting upon author's egotism.

B: P. M. (4II 7$)$

Dimmock, G: Salivary glands in bees. (Psyche, Sep.-Oct. I883, v. 4, p. 87-89, $72 \mathrm{~cm}$.)

Abstract of P. Schiemenz's "Ueber das herkommen des futtersaftes und die speicheldrüisen der biene"... (Zeitschr. f. wissensch, zool., Feb. 1883, v. 38, p. $7^{\text {I-1 } 35)}$ [Rec., 3337].

Dimmock, G: The scales of coleoptera. (Psyche, I883, v. 4: Jan.-Feb., p. 3-I I, fig. I-3; Mch.-Apr., p. 23-27, fig. 4-7; MayJun., p. 43-47, fig. 8-I I ; Jul.-Aug., p. 63-7. I.)

Advance abstract, by author, with same title. (Science, 23 March I883, v. I, p. 203, II cm.)

Abstract, by author, entitled, "Scales of coleoptera." (Science, I Feb. I884, v. 3, p. I 27-I 28, 8 fig.. $38 \mathrm{~cm}$.)

History and bibliography (45 titles) of knowledge of scales of insects, particularly of coleoptera ; enumeration of orders of insects known to possess scales; special description and illustration of hairs and scales of cicindela dorsalis, anthrenus scrophulariae, a. varius, hoplia coerulea, polyphylla variolosa, valgus squamiger, psiloptera drummondi, chalcolepidius rubripennis, alaus oculatus, elateridae sp. incog., ptinus ?rutilus, clytus robiniae, entimus imperialis; mention of scales of related species; general summary of families of scaled coleoptera, forms of scales, colorational effects produced by scales (with tabulation of such effects according to families), causes of coloration in scales, structure of scales, and methods of study of the subject.

$$
\text { B: P. M. (4119) }
$$

[Dipterous larvae in the human stomach.] (Science, 23 Nov. 1883 , v. 2, p. 697,8 cm.) (Psyche, Nov.-Dec. I883, v. 4, p. II9, I I cm.)

Notice of communication made by $A$. Laboulbène at meeting of Société entomologique de France.

$$
B: P . M .(4120)
$$

Dipterous parasite of the rhinoceros.

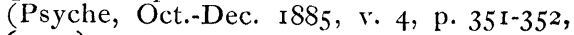
$6 \mathrm{~cm}$.)

Notice of F. Brauer's "Entomologische beiträge" (Verh. K.-k. zool.-bot. ges. Wien, 1884, v. 34, p. 269.271).

Distant, W : Lucas. London letter. (Psyche, Sep.-Oct. I883, v. 4, p. 93-94, 4I cm.)

Statistics of species of insects enumerated and figured, and of new spectes and genera described in Godman and Salvin's "Biologia centrali-americana," prior to July $188_{3}$, according to the several sections of the orders treated; notice of studies of F. Leuthner on mandibular polymorphism of odontolabidae; list of works appearing on lepidopterous faunae of several countries and list of entomological collections being made in neotropical countries. 
Distant, W : Lucas. London letter. (Psyche, Mch. I884, v. t, p. $147-148,38 \mathrm{~cm}$.)

Notice of a collection of Japanese insects made by $\mathrm{G}$ : Lew:s, of the intention of $\mathrm{G}$ : Semper to publish a work on the lepidoptera rhopalocera of the Philippine islands, of the forthcoming of a new edition of $R$. Trimen's "Rhopalocera Africae australis," of the occurrence of a succession of mild winters in England and the influence of such winters on the abundance of insects in the ensuing summers, of the pecuniary value of entomological literature in London, and of a collection of insects and other specimens made by $\mathbf{E}$ : Whym. per in Ecuador; remarks on the sudden and plentiful occurrence of ragadia crisia in the Malay peninsula, where it was previously unknown. $B: P . M$. (4123)

Dodge, C: Richards. Townend Glover. (Psyche, Nov.-Dec. I883, v. 4, p. II 5-I I6, $43 \mathrm{~cm}$.)

Biographical notice of Townend Glover; description of his unpublished illustrated work on North American entomology.

$B: P . M .(4124)$

Dubois, Albert. Preservation of insects. (Psyche, Jan.-Mch. 1885, v. 4, p. 266, Io $\mathrm{cm}$.

Translated extract from Feuille des jeunes natura. listes, Mch. 1885, v. 15, p. 71 ; directions for removing verdigris and grease from insects. $B: P . M .(4125)$

Edwards, W: H : On carrying hibernating larvae through the winter. (Can. entom., June I885, V. I7, p. II3-II4.) (Psyche, Oct.-Dec. I 885 , v. 4 , p. $353-354$, I 7 cm.)

Successful results of artificial hibernation of several larvae of rhopalocera.

$B: P . M$. (4126)

Election of honorary members. (Psyche, Apr.-June r 885 , v. 4 , p. 297,4 cm.)

Notice of election of honorary members of Société entomologique de France.

$B: P . M$. (4127)

Embryology of the silk-worm. (Amer. nat., Apr. I883, v. I7, p. 444.) (Psyche, Mch.Apr. 1883 , v. 4, p. 39,4 cm.)

Histology of amnion and origin of malpighian vessels of bombyx mori studied by S. Salvatico, and rudiments of genital glands of tinea crinella observed by Balbiani. $B: P . M$. $(4128)$

Entomological club of A. A. A. S. (Psyche, Jan.-Mch.1 $88_{5}$, v. 4 , p. $265,8 \mathrm{~cm}$.)

Official announcement of meeting of Entomological club of American association for the advancement of science, to be held 25 Aug. 1885 , at Ann Arbor, Mich. $B: P$. M. (4129)

Entomological items. (Psyche, Jan.-Feb. I 883 , v. 4 , p. $19-20,39 \mathrm{~cm}$.)

B: P. M. (4130)

Entomological items. (Psyche, Mch.-Apr. 1883 , v. 4 , p. $39-40,44$ cm.)

B: P. M. (4131)

Entomological items. (Psyche, May-June I 883 , v. 4 , p. 59,34 cm.)

B: P. M. (4132)
Entomological items. (Psyche, Jul.-Aug. I 883 , v. 4, p. $79-80,44$ cm.)

B: P. M. (4133)

Entomological items. (Psyche, Sep.-Oct. I 883 , v. 4, p. 99-100, 44 cm.)

B: P. M. (4134)

Entomological items. (Psyche, Nov.-Dec. I 883 , v. 4 , p. II9-I $20,45 \mathrm{~cm}$.)

B: P. M. (4135)

Entomological items. (Psyche, Jan.-Feb. I 884 , v. 4 , p. I $39-140,44$ cm.)

B: P. M. (4136)

Entomological items. (Psyche, Mch. I884,

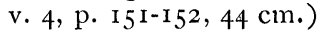

B: P. $M$. (4137)

Entomological items. (Psyche, Apr. I884, v. 4 , p. I63-I64, $45 \mathrm{~cm}$.)

B: P. M. (4138)

Entomological items. (Psyche, May I884, v. 4 , p. $175^{-176,44 \mathrm{~cm} .)}$

B: P. M. (4139)

Entomological items. (Psyche, Jun.-Jul. I 884 , v. 4 , p. I9I-I92, $43 \mathrm{~cm}$.)

B: P. M. (4140)

Entomological items. (Psyche, Aug.-Sep. I 884 , v. 4 , p. 2 I I , 28 cm.)

$B: P . M .(414 \mathrm{I})$

Entomological items. (Psyche, Oct.-Dec. 1884 , v. 4 , p. $233-236$, I33 cm.)

B: P. M. (4142)

Entomological items. (Psyche, Jan.-Mch. I 885 , v. 4 , p. $265-268$, I $32 \mathrm{~cm}$.)

B: $P . M .(4143)$

Entomological items. (Psyche, Apr.-June I 885 , v. 4 , p. $297-300$, I 34 cm.)

B: P. M. (4144)

Entomological items. (Psyche, Jul.-Sep. I $885, \mathrm{v} \cdot 4, \mathrm{p} \cdot 327-328,64 \mathrm{~cm}$.)

B: P. M. (4145)

Entomological items. (Psyche, Oct-Dec. I 885 , v. 4 , p. $35^{\mathrm{I}-354}$, I $28 \mathrm{~cm}$.)

$B: P . M .(4146)$

Entomological society of London. (Psyche, Jul.-Aug. r 883, v. 4, p. 75-76, 22 cm.)

Partial abstract (from Entomologist's monthly maga. zine) of reports of business transacted and communications made at meetings of Entomological society of $\begin{array}{ll}\text { London, } 17 \text { Jan.-2 May } 1883 . & B: P . M . \\ \text { (4147) }\end{array}$

Entomological society of London. (Psyche, Apr.-June I 885, v. 4 , p. 297,3 cm.)

Royal charter granted to Entomological society of London, 20 July 1885 . $B: P$. M. (4148) 
Entomological society of London. (Psyche, Jul.-Sep. I 885 , v. 4, p. 3II-3I4, $125 \mathrm{~cm}$.)

Partial abstract (from Transactions of Entomological society of London, 1883 and 1884) of communications made at meetings of Entomological society of London, 6 June $1883^{-3}$ Sep. 1884 .

B: P. M. (4149)

[Entomological society of Washington.] (Psyche, May I 884 , v. 4, p. I75, 4 cm.)

List of officers of Entomological society of Washing. ton, for 1884 .

$B: P . M$. (4150)

Entomology during the year r883. (Psyche,

Apr.-June I 885 , v. 4, p. 299, Io cm.)

Translation of "Entomologie während des jahres 1883" (Entom. nachrichten, June 1885, v. II, p. I9I).

B: P. M. $(415 \mathrm{I})$

Fernald, C: H: Tortricidae wanted. (Psyche, 1883, v. 4, p. 2, 22, 42, 62, 82, each $3 \mathrm{~cm}$.)

Advertisement.

$B: P . M .\left(415^{2}\right)$

[Final honors in entomology.] (Psyche, Mch. I884, v. 4, p. I 5 r, 9 cm.)

Statement, from The Cornell university register, I883-84, p. I I I, of conditions under which "final honors" in entomology will be conferred upon graduates of The Cornell university.

B: P. M. (4153)

Food-habits and vesicating power of cantharis. (Psyche, Apr.-June I885, v. 4, p. $298,7 \mathrm{~cm}$.)

Notice of H. Beauregard's "Sur le mode de déve. loppement naturel de la cantharide "(Compt.rend. Acad. sci. [Paris], 8 June 1885 , v. 100, p. 1472-1475)."

$$
B: P . M .(4154)
$$

Forbes, Stephen Alfred. On the life-histories and immature stages of three eumolpini. (Psyche, Jan.-Feb. 1884, v. 4, p. 123-I30, $272 \mathrm{~cm}$.; pl. I, with $I$ p. expl. of pl.)

Corrective note, by author, with like title ..."Corrective note." (op. cit., May I884, p. I67-I68, $34 \mathrm{~cm}$.)

Describes larva and pupa of colaspis brunnea, paria aterrima and scelodonta nebulosus (misn.ımed $s$. pubescens); figures imago of the paria and scelodonta, pupa of the scelodonta, larva of the colaspis, head of imago of the paria, and larval and pupal characters of the three species; describes and contrasts the life-histories of these species, referring to previous accounts thereof. $B: P . M$. (4155)

Forbes, Stephen Alfred. On the life-histories and immature stages of three eumolpini [corr.]. Corrective note. (Psyche, May 1884 , v. 4, p. 167-168, 34 cm.)

Corrects and explains erroneous designation of scelodonta nebulosus as $s$. pubescens in author's "On the life-histories and immature stages of three eumol. pinv" (op. cit., Jan..Feb. 1884, p. 123.130) [Rec., 4155]. B: $:$. M.
Fowler, W. W. Collecting coleoptera. (Psyche, Jan.-Feb. I883, v. 4, p. 19, $5 \mathrm{~cm}$.)

Extract from Entomologist, Oct. 1882, v. 15, p. 231 232; description of a method of collecting coleoptera, of which staphylinidae, especially stenus, are the com. monest, especially in winter.

$B: P . M$. (4157)

Friedländer, R. \& sohn. [Natural science publications.] (Psyche, I883-I884, v. 4, p. IO2, I 22, I42, I 54, I66, I $78, \operatorname{each} 6 \mathrm{~cm}$.)

Advertisement.

B: P. M. (4158)

Grote as a composer. (Psyche, Apr.-June 1885 , v. 4, p. $297,4 \mathrm{~cm}$.)

Notice of poems, an essay, and a musical composition by $\mathrm{A}: \mathbf{R}$. Grote.

B: P. M. (4159)

Hagen, Hermann August. The first numero of Thomas Say's American entomology and two letters on the hessian fly hitherto not mentioned among his published papers. (Psyche, Mch. I884, v. 4, p. I 45-146, 54 cm.)

Bibliographical note describing $\mathrm{T}$ : Say's "American entomology"... v. 1, no. 1, Phil., I $8_{17}$, corresponding to plates I, 4, 7, 10, I4 and 18 of Say's work of same title, v. 1, Phil., 1824; notice of two publications by Say in Memoirs of Philadelphia society for promoting agriculture, 1818 , v. 4, p. 224-226 [Rec., 3431] 236-237 [Rec., 3430]. B: P. M. (4160)

[Hagen, Hermann August.] [Hessian fly so called before the Revolution.] (Psyche, Apr. I 884, v. 4 , p. I63, 4 cm.)

Notice of H. A. Hagen's "The occurrence of the hessian fly in North America before the Revolution" (Science, it Apr. 1884, v. 3, p. 432).

B: P. M. (4161)

Hagen, Hermann August. On the relations of fungi to galls and to larvae of cecidomyia living in galls. (Psyche, Oct.-Dec. 1885, v. 4, p. $334,28 \mathrm{~cm}$.)

Reprint, with slight amendment, of H. A. Hagen's paper of same title in Canadian entomologist; state. ment of occurrence of several communities consisting of an insect and a fungus parasitic in a plant gall.

$$
B: P . M .(4162)
$$

Hagen, Hermann August. The tarsal and antennal characters of psocidae. (Entom. mo. mag., June I882, v. I9, p. I2-I3.) (Psyche, May-June I883, v. 4, p. 52, $23 \mathrm{~cm}$.)

Young forms of atropina have two-jointed tarsi, the apical joint becoming divided in later life, the intermediate joints of the antennae increasing in number by division when the number of tarsal joints increases. $B: P . M .\left(416_{3}\right)$

Hazlewood, Francis Tomlinson. Permanent mounting of tracheae of insects. (Psyche, Jan.-Mch. 1885 , v. 4 , p. 253 , Io cm.)

Description of new method of mounting soft parts of insects permanently for the microscope.

B: P. M. (4164) 
[Hermaphroditic lepidoptera.] (Psyche, Jul. I 884 , v. 4 , p. I92, 8 cm.)

Notice of G. Weymer's " $Z$ wei lepidopteren-hermaph. roditen von apatura iris L. und nemeophila russula L." (Jahresber. d. Naturw, ver. in Elberfeld, 1884, heft 6 , p. 74-77), and of C. Cornelius' "Verzeichniss der käfer von Elberfeld und dessen nachbarschaft" ... (op. cit. p. 1-61). $B: \dddot{P}_{.} M .(4165)$

[Hinckley, Mary H.] [Enemies of tadpoles.] (Psyche, Oct.-Dec. I884, v. 4, p. $235,5 \mathrm{~cm}$.)

Partial notice of M. H. Hinckley's "Notes on the peeping frog ..." (Mem. Bost. soc. nat. hist., May I884, v. 3 , no. 10); mention of insect and other enemies of larvae of hyla pickeringii. $\quad B: P . M$. (4166)

Howard, Leland Ossian. Museum pests of service to the entomologist. (Psyche, Jan.Feb. 1884, v. 4, p. 132 , I 2 cm.)

Delicate specimens of insects dissected better by trogoderma tarsale than by the student.

B: P. M. (4167)

Howard, Leland Ossian. Notice of an omission from Leconte's edition of Thomas Say's writings. (Psyche, Aug.-Sep. I884, v. 4 , p. 206, I 5 cm.)

Reprint of note by $\mathrm{T}$ : Say, from Fournal of the Academy of natural sciences, of Philadelphia, Aug. 1817, v. I, p. 63, supplementary to Say's "Some account of the insect known by the name of hessian fly ..." (Journ. etc., July 1817 , v. I, p. 45.48 ), and not reprinted in $J: L$. Leconte's edition of Say's "Complete writings;" comments on Say's erroneous statement that ceraphron destructor sheds its wings after bi eeding; brachypternus individuals occur not uncommonly among pteroinalinae. $B: P . M$. (4168)

Howgate, E: The process of skin-casting in a lepidopterous larva. (Naturalist, Nov. I885, p. 366.) (Psyche, Jul.-\$ep. I885, v. 4, p. $327,22 \mathrm{~cm}$.)

Brief description of the manner in which a geometrid larva cast its skin.

$B: P . M$. (4169)

Hubbard, H: Guernsey. Notes on the habits of hypotrichia spissipes Lec., with description of the females. (Psyche, Oct.Dec. I 884, v. 4, p. 2 I 5-2I 7,78 cm., fig. I3.) Description of method of flight and diurnal habits of male hypotrichia spissipes; description of female imago, with figure of antenna and front tibia and tarsus of male and of female; taxonomic relations of hypotrichia, plectrodes and pleocoma. $B: P . M$. (4170)

[Hudson, G: Vernon.] Pupal retreat of charagia virescens. (Psyche, Jan.-Mch. I 885 , v. 4 . p. $267,23 \mathrm{~cm}$.)

Extracts from G: V. Hudson's "Life-history of charagia virescens" (Entomologist, Feb. 1885, v. 18, p. 30-36).

B: P. M. (4171)

Insects mistaking leaves for flowers. (Psyche, Apr.-June r 885 , v. 4, p. 298, 9 cm.)

Extract from Entom. mo. mag., May 1885 , v. 21, p. 278 , of a commnnication made by $R$. M. Christy and $\mathrm{J}: \mathrm{J}$. Weir to Entomological society of London, I April I885. B: P. M. (4172)
Introduction of humble-bees into New Zealand. (Psyche, Apr.-June I885, v. 4, p. 297,4 cm.)

After repeated attempts, living bombus have been carried from England to New Zealand, to fertilize trifolium pratense. $B: P . M$. (4173)

Jack, J: G: A curious habit of callosamia promethea. (Psyche, May I884, v. 4, p. $169,26 \mathrm{~cm}$.)

Observation on the method by which callosamia pro. methea gains access to long.petioled leaves as food.

$$
B: P . M \text {. (4174) }
$$

[Jones, E. D.] Drinking habit of a moth. (Journ. Roy. micros. soc., Oct. I 884 , s. 2 , v. 4, p. 74I.) (Psyche, Oct.-Dec. I 884 , v. 4 , p. $217,16 \mathrm{~cm}$.)

Abstract of a paper by E. D. Jones (Proc. Lit. and phil. soc. Liverpool, I883, v. 37, p. 76-77); imagos of panthera pardalaria observed to suck up water and pass it through the body in a continuous stream; struc. tural adaptation of the moth to its surroundings.

$B: P . M .(4175)$

[Jordan, R. C. R.] [Apterous female lepidoptera.] (Psyche, Apr. I884, v. 4, p. $163,5 \mathrm{~cm}$.)

List, abstracted from R. C. R. Jordan's " On the European species of lepidoptera with apterous or subapterous females" (Entom. mo. mag., Mch. I884, v. 20, p. 219-22I), of European families of lepidoptera containing apterous or subapterous females. $B: P . M .(4176)$

Karsch, Ferdinand Anton Franz. The entomocecidia. Introduction. (Psyche, Oct.-Dec. I 885, v. 4, p. 331-334, I05 cm.)

Transl., by B : P. Mann, of F. A. F. Karsch's "Die entomocecidien" (Entom. nachrichten, Jul. I884, v. 10, p. 205-209); definition of the nature of galls, list of orders of animals which produce galls, references to prominent monographs on certain classes of galls, and plan of formation of a comprehensive list of galls of insects. $B: P . M .(477)$

[Kent, W. Saville.] Infusorial parasites of white ants. (Psyche, Apr.-June I 885 , v. 4, p. $298,8 \mathrm{~cm}$.)

Notice of communication made by W. S. Kent to Royal society of Tasmania, 17 Nov. 1884 , on infusoria found in termitidae. B:P. M. (4178)

Krancher, Oskar Paul. Want of symmetry among insects. (Psyche, Aug.-Sep. I884, v. 4, p. 200-203, 91 cm., fig. 12.)

Remarks on the prevalent general symmetry of form and coloration in insects, and the rarity of perfect sym. metry or of exact similarity of specimens of one species remarks on varieties, gynandromorphs and cripples; description and figure of a symmetrical cripple of aporia crataegi; description of irregularities in cells of apis mellifica.
B: P. $M$. (4179) 
Krauss, W: Christopher. On the nervous system of the head of the larva of corydalus cornutus Linn. (Psyche, Jun.-Jul. I 884, v. 4, p. I79-1 $84,163 \mathrm{~cm} .$, pl. 2 , with [I $p$. expl. of pl.)

Detailed illustrated description of the anatomy of the nervous system of the head of the larva of corydalus comutus, extracted from a thesis presented to the faculty of the Cornell university for the baccalaureate in science. $\quad B: P$. M. (4ISo)

Landerer, Xaver. [Locusts used as food.] (Psyche, Mch.-Apr. I883, v. 4, p. 39, 5 cm.) Translated extract from Deutsch-amerikanische apotheker-zeitung, I Mch. 1883 . B: P. M. (4181.)

Landerer, Xaver. [Manna.] (Psyche, Jun.-Jul. I 884 , v. 4, p. I9I-I92, 8 cm.)

Translated extract from Deutsch-amerikanische apotheker-zeitung, ${ }_{5}$ May I882, v. 3, p. I.3.

$$
{ }_{B:}^{134} \text { : } . M \text {. (4182) }
$$

[Landerer, Xaver.] Upon a peculiar oriental locality for honey. (Psyche, Jan.-Mch. I 885 , v. 4 , p. $266-26_{7}$, $\left.19 \mathrm{~cm}.\right)$

Translated extract from X. Landerer's "Mittheilungen aus dem orient" (Deutsch-amer. apotheker-zeitung, I5 Dec. I882, v. 3, p. 582); an intoxicating, soporific honey obtained in Persia probably from flowers of papaver; use of this honey as medicine and otherwise, and use of opium in Persia. $\quad B: P . M .(4183)$

Lange, C. F. Exchange of European and American coleoptera. (Psyche, Oct.-Dec. 1884, v. 4, p. 233, $3 \mathrm{~cm}$.)

Advertisement.

B: P. M. (4184)

[Leaping ant.] (Science, I4 Sep. I883, v. 2, p. 386, 4 cm.) (Psyche, Sep.-Oct. I 883 , v. 4 , p. 99,5 cm.)

Notice of communication by E. Lefèvre at meeting of Société entomologique de France, in July i 883. $B: P . M .(4185)$

[Leconte, J : Lawrence; obituary notice of.] (Psyche, Nov.-Dec. I883, v. 4, p. I I9, IO $\mathrm{cm}$.)

Obituary notice of $\mathrm{J}$ : Lawrence Leconte; explanatory note regarding $C: V$. Riley's "Tribute to the memory of John Lawrence Leconte" (hoc op., p. 107.110) [Rec., 4263 .

$B: P . M .(4 \mathrm{i} 86)$

[Leidy, Joseph.] [Habits of lasius interjectus.] (Psyche, Jan.-Feb. I883, v. 4, p. I9, $5 \mathrm{~cm}$.)

Abundance of lasius interjectus near Philadelphia, $\mathrm{Pa}$. ; care of aphids and coccids by this ant

$$
\text { B: P. M. (4187) }
$$

[Lendenfeld, R.] [Muscular contraction in flight.] (Science, I9 Dec. I884, v. 4, p. 562, $2 \mathrm{~cm}$.) (Psyche, Oct.-Dec. I 884 , v. 4 , p. $234,4 \mathrm{~cm}$.)

Notice of paper read by Dr. R. Lendenfeld before Linnean society of New South Wales, 29 Oct. 1884; muscular contraction stated to occur in flight of insects. $B: P . M .(4188)$
Life of Dr. Dzierzon. (Psyche, Oct.-Dec. I $\left.88_{5}, \mathrm{v} . \mathrm{t}, \mathrm{p} .35 \mathrm{I}, 5 \mathrm{~cm}.\right)$

Notice of a biographical sketch of Johann Dzierzon by $\mathrm{O} . \mathrm{P}$. Krancher in Deutscher bienenfireund, Jan. 1885 . $B: P . M .(4189)$

Linnean society of London. (Psyche, MayJune I 883 , v. 4 , p. $54.13 \mathrm{~cm}$.)

Abstract (from Zoologischer anzeiger, $5 \mathrm{Mch}$. $188_{3}$, v. 6 , p. 127.123) of communication made by J. M. Camp. bell, at meeting of Linnean society of London, 6 Feb. $188_{3}$, on pairing of tegenaria guyonii, with description of some glands on the abdominal sexual region of the male of this species. $B: P . M$. (4190)

Linnean society of London. (Psyche, Sep.Oct. I 883 , v. 4 , p. 92-93, 33 cm.)

Partial abstract (from Zoologischer anzeiger) of com. munications made at meetings of Linnean snciety of London, ${ }_{5}$ Feb. -7 June 1883 . $B: P . M$. (419I)

Linnean society of London. (Psyche, Aug.Sep. 1884, v. 4, p. 206, I I cm.)

Partial abstract (from Zoologischer anzeiger, by J. Murie) of communications made at meetings of Linnean society of London, 20 Dec. 1883 and 17 Jan. $188_{4}$.

$$
\underset{B: P . M .}{ } \text { (4192) }
$$

Linnean society of London, (Psyche, Jan.Mch. 1885 , v. 4 , p. 254,29 cm.)

Partial abstract (from Zoologischer anzeiger, by J. Murie) of communications made at meetings of Linnean society of London, 21 Feb.-20 Nov. 1884.

$$
\text { B. P. M. (4193) }
$$

Linnean society of New South Wales. (Psyche, Jul.-Aug. 1883 , v. 4, p. $76,9 \mathrm{~cm}$.)

Abstract (from Zoologischer anzeiger, 9 Jul. 1883, v. 6 , p. $37^{6}$ ) of communication made by W: Macleay at meeting of Linnean society of New South Wales, 25 Apr. $18 S_{3}$; account of ravages of a tineid moth in vegetable gardens at Sydney, N. S. W.; exhibition (by Stevens) of chrysalis of danais attached to leaf of pelargonium.

$B: P . M(4194)$

Linnean society of New South Wales. (Psyche, Apr.-Jun. I885, v. 4, p. 287-288, $19 \mathrm{~cm}$.)

Partial abstract (from Zoologischer anzeiger) of communications made at meetings of I innean society of New South Wales, 29 Aug. 1883-31 Dec. 1884.

$B: P . M$. (4195)

Lintner, Joseph Albert. Book notice. (Psyche, May-June I 883 , v. 4, p. 53 , I I cm.) Anticipatory notice of W: Saunders' "Insects injurious to fruits," Phil., I883: need, value and scope of the work. $B: P . M$. (4196)

Lintner, Joseph Albert. Captures of feniseca tarquinius Fabr. (Psyche, Jul.-Aug. r883, v. 4 , p. 75 , I $4 \mathrm{~cm}$.)

Record of several captures of feniseca tarquinius in eastern New York. 
Lintner, Joseph Albert. [Collection of "cut-worms."] (Psyche, Jul.-Aug. I883, v. 4 , p. 80, Io cm.)

Notice of paper read by Mrs. Mary Treat before New Jersey state horticultural society, in January $13 S_{3}$; attraction of cut-worms to phlox, and their collection therefrom.

$$
B: P . M \text {. (4198) }
$$

Lintner, Joseph Albert. On an egg-parasite of the currant saw-fly, nematus ventricosus. (P-yche, May-June I $88_{3}$, v. 4, p. 4र-5I, I 28 cm.)

Observations made in 1866,1867 and 1868 , upon the food-habits and oviposition of trichogramma pretiosa, with reprint of comments by Asa Fitch thereon (12th ann. rept. ins. N. Y. for I 867 ) (Trans. N. Y. state agric. soc. for 1867,1869, v. 27 ), p. $93^{1-932}$; rediscovery of this parasite in $\mathrm{IS82}$; attempt to scatter specimens over United States and Canada; other occurrences and known hosts of the insect; parasitism of $t$. minuta in eggs of limenitis disippus; oviposition of nematus ventricosus. $B: P . M .(4199)$

Lintner, Joseph Albert. A new sexual character in the pupae of some lepidoptera. (Psyche, Nov.-Dec. I883, v. 4, p. I03-106, I $33 \mathrm{~cm}$.)

Mention of primary and secondary sexual characters hitherto observed in insect imagos and pupae, and presumed characters discovered in pupae of cossinae and aegeriidae.

$B: P . M .(4200)$

Lintner, Joseph Albert. [Platygaster larva parasitic upon galls of cecidomyia salicisbatatus.] (Psyche, Jul.-Aug. I883, v. 4, p. $79,8 \mathrm{~cm}$.)

Notice of D: S. Kellicott's account, in Bulletin of the Buffalo naturalists' field club, Mch. Is $\mathrm{S}_{3}$, of platy. gaster larva parasitic upon galls of cecidomyia salicis. batatus. B: P. M. (420I)

Lintner, Joseph Albert. Rearing lepidoptera. (Psyche. May-June I883, v. 4, p. 53, I $4 \mathrm{~cm}$.

Notice of labors and success of S. L. Elliot in breed. ing and rearing lepidoptera, and carrying pupae through the winter.

[Löw, Franz.] Waxy secretions of psyllid larvae. (Psyche, Jul.-Sep. I885, v. 4, p. $310,9 \mathrm{~cm}$.)

Translated extract from F. Löw's "Beiträge zur kenntniss der jugendstadien der psylliden" (Verh. K.-k. zool..bot. gesells. in Wien, 1884, v. 34) [Rec., 4014].

B: P. M. (4203)

[Looss, - . ] New solvent of chitin. (Psyche, Apr.-Jun. 1885 , v. 4 , p. 286 , I9 cm.)

Abstract of -. Looss' "Neue lösungsmittel des chitins" (Zool. anzeiger, I June 1885, v. 8, p. 333-334).

[Lowne, B: Thompson.] [Compound vision of insects.] (Psyche, Oct.-Dec. 1884, v. 4, p. $235,9 \mathrm{~cm}$.)

Extract from report by J. Murie, in Zoologischer anzeiger, 3 March $1884, v .7, p .127$, of meeting of Linnean society of London, 7 Feb. 1884. [Author's name given as B. J. Lowne.] B:P.M. (4205)
Lugger, O: Food-plants of beetles bred in Maryland. (Psyche, Aug.-Sep. I884, v. 4, p. $203-204,24 \mathrm{~cm}$.)

List of 37 coleoptera and of the trees from the wood (in one case seed) of which they were respectively bred.

$B: P . M .(4206)$

[Lugger, O :] [Parasites of tiphia.] (Science record, 15 Aug. I884, v. 2, p. 232.) (Psyche, Aug.-Sep. 1884 , v. 4, p. 2 I I, $7 \mathrm{~cm}$.)

Crit. rev., by C: V. Riley, entitled "Parasites of the larva of lachnosterna fusca." (Psyche, Oct.-Dec. I884, v. 4, p. 224, 9 cm.) Hymenopterous parasites occurring in cocoons of tiphia, the larvae of the tiphia being infested by larvae of rhipiphorus pectinatus or r. limbatus and being them. selves parasitic on larvae of lachnosterna fusca; the first mentioned parasites supposed to prey upon the rhipipho. rus.

$B: P . M .(4207)$

[Macleay, W:] [Helix-like egg-cases.] (Psyche, Oct.-Dec. I 884 , v. 4, p. $235,4 \mathrm{~cm}$.) Notice of communication made by $\mathrm{W}$ : Macleay to Linnean society of New South Wales, June I884. $B: P . M .(4208)$

Macloskie, G : Gills of insect-larvae. (Psyche, Nov.-Dec. I883, v. 4, p. I IO-I I 2, $68 \mathrm{~cm}$.)

Nature of gills of insect-larvae defined; contrary to the view usually held regarding them, the tracheae therein terminate caecally and not in recurrent loops; action of tracheae tidal.

$B: P . M .(4209)$

Macloskie, G: Head of larval musca: preliminary note. (Psyche, Oct.-Dec. I884, v. $4, p$ 218-2 I $9,44 \mathrm{~cm}$.)

Description of structure of head in larva of musca caesar, homologizing the several parts with those of imago.

$$
B: P . M .(4210)
$$

[Maeklin, F: W:; obituary notice of.] (Psyche, Mch.-Apr. I $88_{3}$, v. 4, p. 39,6 cm.)

Extract from American naturalist, Apr. 1883, v. I7,
B:P.M. (4211) p. 424 .

Mann, B : Pickman, treasurer. Acknowledgement of contributions. (Psyche, Aug.Sep. 1884, v. 4, p. 2 I I-21 2, $39 \mathrm{~cm}$.)

B: P. M. (4212)

Mann, B : Pickman, treasurer. Acknowledgments. (Psyche, Oct.-Dec. I885, v. 4, p. $330,7 \mathrm{~cm}$.)

Acknowledgment of contributions to permanent publication fund of Psyche. $B: P . M .\left(4^{213}\right)$

Mann, B: Pickman, ed. Bibliographical record. (Psyche, I883-1885, v. 4, p. I5-18, 33-38, 55-58, 77-78, 95-98, I I 7-I I 8 , I 35 - 138 , I 49-1 50, I6I-I62, I 7 I-I 74, I 87-190, 207-2 10, 227-232, 255-264, 289-296, 3 I 5-326, 339-350, $350^{*}-350^{* *}$. .)

List of publications on entomology, being no. 3 Ior. 4300 of the Bibliographical record of PSYCHE, containing exact titles of and references to and brief analyses of each publication recorded, with occasional explanations of the method of record. $B: P . M .(4214)$ 
Mann, B : Pickman. The bibliography of entomology. Annual address of the retiring president of the Cambridge entomological club, I I January i 884. (Psyche, Apr. 1884, v. 4, p. I 55-1 59. I 35 cm.)

7 th annual address of retiring president of Cambridge entomological club; remarks upon the interest of the club in biblingraphical work, upon the importance of bibliography, upon the scope of existing periodicals of zoological bibliography, upon the value of $\mathrm{H}$. A. Hagen's "Bibliotheca entomologica" [Rec., 3306], and upon the Bibliographical record of PSYCHE.

$B: P . M$. (4215)

Mann, B : Pickman. [Biographical notice of W: C. Krauss.] (Psyche, Jun.-Jul. I884, v. 4 , p. I $9 \mathrm{I}, 7 \mathrm{~cm}$.)

Notice of graduation of $\mathrm{W}:$ Christopher Krauss from The Cornell university, 19 June $188_{4}$; extension of welcome to philosophical entomologists. $B: P . M .(4216)$

Mann, B : Pickman. Close of volume four. (Psyche, Oct.-Dec. 1885, v. 4, p. 335, I I cm.)

Valedictory address of $B: P$. Mann as managing editor of PSYche; explanation of the scope of the systematic and alphabetic indices of volume four.

$B: P . M \cdot(4217)$

Mann, B: Pickman. Contribution to the knowledge of parasitic life in galls. (Psyche, Sep.-Oct. I 883, v. 4 , p. $89-9$ I, $88 \mathrm{~cm}$.)

Engl. transl. of G. F. Möllers "Bidrag till kännedomen om parasitlifvet i galläpplen" ... (Entom. tidskr., I882, v. 3, p. I82-186) [Rec., 3397]; lists of insects other than the gall-makers ratised from galls of several species of cynipidae in Sweden. $B: P . M .(4218)$

Mann, B : Pickman, transl. The double role of the sting of the honey-bee. (Psyche, Jan.-Mch. 1885 , v. 4 , p. $25 \mathrm{I}-25^{2}, 66 \mathrm{~cm}$.)

Translation, by B : P. Mann, of "Ueber eine doppelrolle des stachels der honigbienen" (Deutsch-amer. apotheker-zeitung, 15 Jan. I885, v. 5, p. 664) [Rec., 3722]. $B: P . M$. (4219)

Mann, B : Pickman, secretary. [Entomological society of Washington.] (Psyche, Mch. I 884 , v. 4, p. I 5 I, 5 cm.).

Notice of preliminary organization of Entomological society of Washington, 29 Feb. $1884 . \quad B: P . M$. (4220)

Mann, B : Pickman. Eudamus tityrus flying at night. (Psyche, Oct.-Dec. 1885, v. 4, p. $35^{2}$, $10 \mathrm{~cm}$.)

Communication made to Cambridge entomological club, i Dec. I885; behavior of eudamus tityrus attracted to artificial light at night.

$B: P . M .(4221)$

Mann, B : Pickman. False dates. (Psyche, Mch.-Apr. 1883 , v. 4 , p. 3I-32, 45 cm.)

Comments on the value of a systematic statement of dates of issue of scientific periodicals, and the falsity as well as unreliability of such statements when made in connection with the issues dated; thesis illustrated by a table of announced and actual dates of issue of volumes 20 and 21 of Proceedings of Boston society of natural history.
Mann, B: Pickman. Food-plants of pulvinaria innumerabilis. (Psyche, Oct.-Dec. I 884, v. 4, p. $224,20 \mathrm{~cm}$.)

List of food-plants of pulvinaria innumerabilis, compiled from various authorities: type specimens deposited in Museum of comparative zoology, Cambridge, Mass. $B: P$. M.' (4223)

Mann, B: Pickman. Francis Gregory Sanborn. (Psyche, Aug.-Sep. I884, v. 4, p. $205,26 \mathrm{~cm}$.

Obituary notice of Francis Gregory Sanborn.

$B: P . M .(4224)$

Mann, B : Pickman. Herbert Knowles Morrison. (Psyche, Apr.-Jun. I 88.5, v. 4, p. $287,22 \mathrm{~cm}$.)

Obituary notice of H. K. Morrison. B: P. M. (4225)

Mann, B : Pickman. Index to entomological literature. (Psyche, I884-1885, v. 4, p. 214, 238, 270, 302, each $4 \mathrm{~cm}$.)

Advertisement.

B: P. $M .(4226)$

Mann, B : Pickman. Index to entomological literature. (Psyche, Oct.-Dec. I 884, v. 4, p. $223,27 \mathrm{~cm}$.)

Remarks upon the economy of a division of labor by which special students may be spared the necessity of searching through miscellaneous literature for writings upon their specialties; statement of plan for such division of labor; solicitation of contribution of special reference lists to the pages of PSYcHE.

B: P. M. (4227)

Mann, B : Pickman. The influence of meteorological conditions on insect life. (Psyche, Sep.-Oct. I883, v. 4, p. $83-87$, I $46 \mathrm{~cm}$.)

Abstract of C: G. Barrett's paper of same title (Entom. mo. mag., June 1882, v. 19, p. 1-8) [Rec., 3889]; effect of severely cold winters in promoting the ahund ance of certain species of lepidoptera, and of wet weather in destroying other species.

$B: P . M .(4228)$

Mann, B : Pickman and Dimmock, G : Introduction to the fourth volume. (Psyche, Jan.-Feb. 1883 , v. 4, p. $12-13,36 \mathrm{~cm}$.)

Statement of the material and editcrial conditions under which the publication of the fourth volume of PSYche is inaugurated. $B: P . M$. (4229)

Mann, B : Pickman. [References to galls and gall-insects.] (Psyche, Mch. I884, v. 4 , p. $147,6 \mathrm{~cm}$.)

Notice of publication in Bibliographical record of Psyche, of references to galls and gall-insects, and of reservation of references not ready for publication; offer to supply manuscript references in exchange for equivalent returns. $\quad B: P . M$. (4230)

Mann, B : Pickman. Review. (Psyche, Jun.-Jul. 1884 , v. 4 , p. $185,28 \mathrm{~cm}$.)

Critical notice of J: H : Comstock's "(A fragment of a) Guide to practical work in elementary entomology" [Rec., 3508]; comments on the peculiar terms of anatomical description used in the work. $B: P . M .(4231)$ 
Mann, B : Pickman. Vactor Tousey Chambers. (Psyche, Sep.-Oct. 1883, v. 4, p. 94, I5 cm.)

Biographical notice of Vactor Tousey Chambers; list of his entomological writings recorded in PsYcHE.

Mann's reference indexes. (Psyche, Oct.Dec. 1885 , v. 4 , p. $330,2 \mathrm{~cm}$.)

Advertisement.

B: P. M. (4233)

[Medicinal use of blatta orientalis.] (Psyche, Nov.-Dec. I883, v. 4, p. I I9-I 20 , I 1 cm.)

Extract from abstract (in Deutsch-amerikanische apotheker-zeitung, I Apr. 1883, v. 4, p. 49) of paper by T. Boyomolow (in St. Petersburg medicinische zuochenschrift).

B: P. M. (4234)

Müller, Fritz. Butterflies as botanists.

(Nature, Io Jul. I 884 , v. 30, p. 240.)

(Psyche, June-Jul. r884, v. 4, p. r9I, 7 cm.)

The use of certain plants as food by lepidoptera revealed an appreciation of the true relationship of the genera before the same was recognized by authors.

$$
B: P . M .(4235)
$$

[Müller, Hermann; memoir of.] (Amer. nat., Aug. I884, v. I8, p. 848.) (Psyche, Aug.-Sep. I 884 , v. 4, p. 2 I I, 3 cm.)

Notice of publication, by Ernst Krause, of memoir with portrait and list of writings of Hermann Muiller. B: P. M. (4236)

Munn \& co. Patents. (Psyche, r883-1885, v. 4 , p. 102, I22, 1 42, I 54, I66, I78. I94, each $4 \mathrm{~cm}$; p. 302, $9 \mathrm{~cm}$.)

Advertisements.

B: P. M. (4237)

Munn \& co. Scientific american. (Psyche, I884-1885, v. 4, p. 214, 238, 270, each $8 \mathrm{~cm}$.) Advertisement.

B: P. M. (4238)

Murtfeldt, Mary Esther. A butterfly attracted by lamp-light. (Psyche, Aug.-Sep. I 884 , v. 4, p. $206,7 \mathrm{~cm}$.)

Narration of two instances of the attraction of apatura lycaon by lamp-light at night. $\quad B: P . M .\left(4^{239}\right)$

Murtfeldt, Mary Esther. Sexual characters in the chrysalids of grapta interrogationis. (Psyche, Jun.-Jul. I884, v. 4 , p. I 84, I 7 cm.) Statement that pale and gilded chrysalids of grapta
interrogationis yielded female imagos, while males were obtained from darker colored chrysalids withou brillıant ornamentation. B: P.M. $\left(4^{240}\right)$

[Necrology.] (Psyche, Jun.-Jul. I884, v. 4, p. I9I, $4 \mathrm{~cm}$.)

Obituary notices of J. C. Schiödte, Edwin Birchall and $\mathrm{W}$ : Prest.

B: $P . M$. (4241)

[Necrology.] (Psyche, Oct.-Dec. I884, v. 4 , p. $236,13 \mathrm{~cm}$.)

List of entomologists recently deceased, with dates of the birth and death and with characterization of some of them.
[New scientific journals.]

I 884 , v. 4 , p. I 5 I, I $3 \mathrm{~cm}$.)

(Psyche, Mch.

Notice of several ephemeral scientific periodicals recently begun, and condemnation of the waste of effort involved in such publications. $B: P . M$. (4243)

Notices to entomologists. (Psyche, MayJune 1883 , v. 4 , p. 60 , ro cm.)

Call, by J. A. Lintner, of a meeting of entomologists to be held at Minneapolis, Minn., 15 Aug. 1883 ; and by B : P. Mann and G: Dimmock, of a special public meet. ing of Cambridge entomological club to be held at the same place, ${ }_{4}$ Aug. 1883 . $\quad B: P . M$. (4244)

[Ord, W: M.] Erosion of glass. (Psyche, Oct.-Dec. 1885 , v. 4 , p. $35^{2}, 8$ cm.)

Abstract of W: M. Ord's "Erosion of glass" (Nature, 19 Feb. 1885, v. 31, p. 360); chemical explanation of erosion of glass by "mud" formed by termitina. $B: P^{3} . M \cdot(4245)$

Osborne, J: A. [Position of embryo in eggs of insects.] (Psyche, May I884, v. 4, p. I75-I $76,9 \mathrm{~cm}$.)

Extract from J: A. Osborne's "Some further observations on the parthenogenesis of zaraea fasciata" ... (Entom. mo. mag., Dec. 1883, v. 20, p. $\left.{ }^{145^{-1}} 4^{-1}\right)$.

$B: P$ : $M$. (4246)

Parasitic [corr.] nematods. (Psyche, Oct.Dec. 1885 , v. 4 , p. $35^{2-353}$, Io cm.)

Notice of communication made by $\mathbf{H}$. Gadeau de Kerville to Société entomologique de France, 9 Sep. 1885 , and of $\mathrm{O}$ : Linstow's "Compendium der helminthologie" ... Hannover, 1878 [Rec., 3119].

$$
B: P . M .(4247)
$$

[Passerini, Napoleone.] Observations on decapitated silkworm moths. (Psyche, Apr.-Jun. I 885, v. 4 , p. 288, I 7 cm.)

Abstract of N. Passerini's "Esperienze sulla decapitazione delle farfalle del baco da seta" (Bull. Soc. entom. ital., 3i Dec. 1884, v. I6, p. 285-286). B: P. M. (4248)

Patton, W: Hampton. Sound-producing organs in anomala, anthonomus, and other coleoptera. (Psyche, Mch. I884, v. 4, p. $146, I_{5} \mathrm{~cm}$.)

Statement of occurrence of stridulating organs in several scarabaetdae and elateridae and in curculioni. dae; description of location of these organs. B: P. M. (4249)

[Phylloxera in Silesia.] (Science, 2 I Nov. I884, v. 4, p. 48r, 2 cm.) (Psyche, Oct.Dec. I 884 , v. 4 , p. $233,2 \mathrm{~cm}$.)

Notice of appearance of phylloxera vitifoliae in Proskau, Silesia. $B: P . M .(425 \mathrm{c})$

[Phylloxera precautions at Argentine custom-house.) (Psyche, Jan.-Feb. I884, v. 4 , p. $139,4 \mathrm{~cm}$.)

Notice, translated from El nacional, $8 \mathrm{Sep}$. $188_{3}$, p. r, col. 8, of prohibition of importation of grape-vines at Buenos Aires, to avoid danger of introduction of phyl. loxera vitifoliae. $B: P . M .(425 \mathrm{I})$ 
[Phytophagous carabidae.] (Psyche, Oct.-Dec. 1884, v. 4, p. 234,4 cm.)

Notice of communications by A. C. Horner and T. H. Hart, in Entomologist, Oct. and Nov. IS84.

$$
\text { B: P. M. (4252) }
$$

[Poujade, Gustave Arthur.] [Predominance of genital functions.] (Psyche, Oct.Dec. 1884 , v. 4 , p. 236 , i i cm.)

Translation of communication made by G. A. Pou jade to Société entomologique de France, 23 July i 884 ; movements of genital organs in brephos, rhodocera rhamni and lucanus cervus observed after these insects were otherwise dead.

B: P. $M$. (4253)

[Practical naturalist (The).] (Psyche, Nov.-Dec. 1883 , v. 4, p. I $16,6 \mathrm{~cm}$.)

Notice of Practical naturalist, no. $1-7$, published by Ward and Riley at Bradford, England.

$$
\text { B: P. M. (4254) }
$$

[Preparation of duplicate coleoptera.] (Psyche, Jan.-Feb. I8S4, v. 4, p. I $40,6 \mathrm{~cm}$. )

Reprint from Science record, Nov. $188_{3}$, v. 2, p. 15-16; recipe for a solution, such as that used by $J: B$. Smith, in which to soak certain insects to render them not liable to break.

B: $P . M$. (4255)

Preservation of honey. (Sci. amer., I8 Nov. 1882, [v. 6r] , n. s., v. 47, p. 324.) (Psyche, Jan.-Feb. I883, v. 4, p. I9, $4 \mathrm{~cm}$.) Presence of formic acic in crude honey, and effect of this acid in preventing fermentation. B: $P . M .(4256)$

Preservation of insects. (Psyche, Apr.June 1885 , v. 4 , p. $298,8 \mathrm{~cm}$.)

Translation of a paper in Feuille des jeunes natura. listes, Apr. 1885 , v. 15 , p. 81 ; method of use of solution of naphthalin in benzin to prepare hairless insects for the cabinet (by - Jacobs); verdigris removed from pins by ammonia (by C: Zuber). B:P.M. (4257)

Prize work on tactile organs. (Psyche, Oct.-Dec. 1885 , v. 4 , p. 35 I, 2 cm.)

Notice of grant, by Académıe des sciences de France, to J. Chatin, of grand prize for a work on tactile organs of insects and crustacea.

$B: P . M$. $(4258)$

Proceedings of societies. (Psyche, r883I 885 , v. 4, p. 13-I $4,32,54,75-76,92-93$, I 6 , I33-I34, I 47, I6o, I70, I86, 206, 224-226, 253-254, 287-288, 3 I I-3 I 4, 335-338.)

For further record, see names of respective societies. B: P. M. (4259)

Prognostications of weather by insects. (Psyche, Jul.-Sep. I885, v. 4, p. 327-328, $4 \mathrm{I} \mathrm{cm}$.)

Notice, extracted from "[Bees as storm-warners]' (Nature, 23 Apr. 1885, v. 31, p. 587), of article by -. Emmerig (Natur, 1885 , no. 17 ), on the behavior of apis mellifica as indicative of the approach of thunderstorms; extracts from and references to other articles on the subject.
Riley, C: Valentine. Galls and gall insects. (Psyche, I883, v. 4, p. 2, 22, 42, 62, 82, each $3 \mathrm{~cm}$.)

Advertisement.

B: P. M. (426I)

Riley, C: Valentine. Parasites of the larva of lachnosterna fusca. (Psyche, Oct.-Dec. I 884, v. 4, p. $224,9 \mathrm{~cm}$.)

Crit. rev. of [O: Lugger's] "[Parasites of tiphia]" (Psyche, Auv..Sep. I\$S4, v. 4, p. 211) [Rec. 4207] tiphia larvae externally parasitic on larvae of lachno. sterna fisca, beyinning to feed as sonn as hatched; eggs of rhipiphorus probably laid on flowers frequented by tiphia, the triungulins attaching themselves to the tiphia and carried by it to the nest. $B: P . M .(4262)$

Riley, C: Valentine. Tribute to the memory of John Lawrence Leconte. (Psyche, Nov.-Dec. I883, v. 4, p. Io7-I Io.)

Separate. [Cambridge, Mass., Feb. I884.] n. t.-p., p. IO7-1 10, $25 \times$ i 8 .

Notice. (Psyche, ut cit., p. I I9.)

Germ. tr., [by F. Katter], entitled, "Zum gedächtniss von John Lawrence Leconte." (Entom. nachrichten, June I884, jahrg. Io, p. I83-186.)

Biographical notice of J: L. Leconte; amount, character and importance of Leconte's work and writings; his personal character; his relations with $\mathrm{G}: \mathrm{H}$ : Horn; disposition of his entomological collection.

B: P. M. (4263)

[Ross, M. Louisa.] South American insects for sale. (Psyche, Jan.-Mch. I885, v. 4, p. $265,5 \mathrm{~cm}$.)

Advertisement.

B: P.M. $(4264)$

$\mathbf{R}$ [ye], E : Caldwell. Influence of color on insects. (Psyche, Nov.-Dec. I883, v. 4, p. $114,16 \mathrm{~cm}$.

Extract from E. F. imThurn's account (Timehri, v. 1, pt. 2, p. 223) of a visit to Mt. Russell in Guiana; yellow butterflies attracted to yellow flnwers, and blue morpho to decaying banana-skins, but red species not attracted to red fruit; butterflies entrapped under a basket. $B: P . M .(4265)$

[Saunders, Sidney Smith; obituary notice of.] (Nature, I7 Apr. I884, v. 29, p. 58r.) (Psyche, May I 884, v. 4 , p. I 75,4 cm.)

Sir Sidney Smith Saunders, entomologist, b. June 1809, d. 15 April 1884; especial student of stylopidae. B: P. M. $(4266)$

[Schulgin, M.] [Imbedding material.] (Psyche, Jan.-Feb. 1883 , v. 4, p. 19, $3 \mathrm{~cm}$.) Notice of M. Schulgin's" Zur technik der histologie" (Zool. anzeiger, 8 Jan. 1883, v. 6, p. 21-22).

$$
B: P . M .(4267)
$$

Scudder, S: Hubbard. Early stages of butterflies wanted. (Psyche, I883, v. 4, p. $2,22,42,62,82$, I02, each $4 \mathrm{~cm}$.)

Advertisement; same as Rec., 3085. B: P. M. (4268) 
Scudder, S: Hubbard. The geological history of myriopods and arachnids.... (Psyche, Jan.-Mch. 1885, v. 4, p. 245-250. $204 \mathrm{~cm}$.)

8th annual address of retiring president of Cambridge entomological club; morphology and phylogeny of the several suborders of myriopoda; occurrence and distri. bution of these suborders and of those ot arachnida in the several geologic strata, with tables. [Certain errors in the tables are referred to by author in Comptes.ren. dus Entom. soc. Belg., 6 March 1886, p. 63.1

$$
\text { B: P. M. (4269) }
$$

Scudder, S: Hubbard. Notes on melittia cucurbitue and a related species. (Psyche, Jul.-Sep. $188_{5}$, v. 4, p. 303-304, 66 cm.)

Description of larva of melittia cucurbitae and of larva presumed to be of a smaller species of melittia, both found in cucurbita vines on Cape Cod, Mass.; com. parison between life-habits of the two. $B: P . M .(4270)$

Serpin, - - \Making insect powder from tar.] (Psyche, Mch.-A pr. 1883, v. 4, p. 40, $6 \mathrm{~cm}$.

Translated extract from Deutsch-amerikanische apotheker-zeitung, $\mathrm{I}$ Mch. $188_{3}$. B: P. M. (4271)

Snow, Francis Huntington. Hominivorous habits of lucilia macellaria, "the screwworm." (Psyche, Mch.-Apr. I 883, v. 4, p. $27-30$, r $27 \mathrm{~cm}$.)

Crit. rev., by J. M. F. Bigot. (Bull. Soc. entom. France, I 2 Sep. 1883 , no. I7, p. I 54-I.5.)

Notice, in S: W. Williston's 'The screwworm fly"... (Psyche, Nov.-Dec. I883, v. 4 , p. I I 2-I I 4).

Accoun:s, in part qu'ted from acc $u$ unts given by $S$. D. Osborn, J. B. Britton and Jeshua Richardson, of several cases in which larvae of lucilia macellaria, deposited by the parent $\mathrm{fly}$ in nostrils of men, caused death or severe illness; inclur!es notes, by $\mathbf{S}: \mathbf{W}$. Willis. ton, on the synonyms, relationship and geographical ton, ont the synonyms, relationship and geographical
disti ibution of this fly.

Society meeting;. (Psyche, I883-1885, v. 4, p. $20.40,60,80,100,120,140,152$, I64, I 76,192 , each $23 \mathrm{~cm}$.)

List of dates of meetings of several entomolngical societies. B: P. M. (4273)

[Sprague, Frank Ileadley.] [Rare diurnal lepidoptera in Massachusetts.] (Psyche, Sep.-Oct. I 883 , v. 4 . p. 99-100, $8 \mathrm{~cm}$.)

Record of captures of rare lepidoptera rhopalocera in Massachusetts, in $\mathrm{ISS}_{3}$

B: P. M. (4274)

Staphylinidae of Buenos Aires. (Psyche, Jan.-Mch. $188_{5}$, v. 4 , p. $265,5 \mathrm{~cm}$.)

Notice of F. L. Arribálzaga's "Estafilinos de Buenos Aires" (Boletin Acad. nac. sci. Córdob:, i $188_{4}$, v. 7 , p. $1 \cdot 392)$.
Stebbins, Solomon. North American ferns. (Psyche, I883, v. 4, p. 2, 22, 42, 62, 82, each $2 \mathrm{~cm}$.)

Advertisement.

B: P. M. $(4276)$

Strecker, Herman. Abnormal specimens of samia and allies. (Psyche, Jul.-Sep. I 885 , v. 4 , p. 312-3 I3, I I cm.)

Crit. rev. of W. F. Kirby's "Abnormal specimen of the genus samia" (Trans. Entom. soc. Lond., I883; Proc., p. 27); the specimen described by Kirby is a suffused aberration of samia cecropia; description of aberrant forms of telea polyphemus, antheraea yamamai and tropaea luna.

B: P. M. (4277)

Structure and habits of oedematophaga agusalis. (Psyche, Oct.-Dec. I 885, v. 4, p. $3.5 \mathrm{r}, 6 \mathrm{~cm}$.)

Notice of a part of E: Meyrick's "On the classitication of Australian pyralidae" (Trans. Entom. soc. Lond., $\mathrm{ISS}_{4}$, p. 61-80). B: P. M. (4278)

Structure of the eyes of diptera. (Psyche, Oct.-Dec. I 885 , v. 4, p. $35^{\mathrm{I}}, 6 \mathrm{~cm}$.)

Transl. of notice, in Entomologische nachrichten, May 18S5, v. I1, p. 144, of G. V. Ciaccio's "Figure di. chiarative della minuta fabbrica degli occhi de' ditteri" (Mem. della R. accad. dell' Istituto di Bologna, $\mathrm{ISS}_{5}$, s. 4 , v. 6, fasc. $1 ; 28$ p., 12 pl.) B: P. M. (4279)

[Tincture of black ants for scurvy.] (Psyche, May-June 1883 , v. 4 , p. 59,6 cm.)

Abstract of note entitled "Ameisen gegen skorbut," in Deutsch-amerikanische apotheker-zeitung, I Apr. ${ }_{18 S_{3}}$, v. 4, p. 49 . B: P. M. (4280)

Tomato-plants as repellants of insects. (Psyche, Oct.-Dec. I885, v. 4, p. 353, I 2 cin.)

Reprint of " $\lfloor$ 'Tomatoes as a prophylactic against insects]" (Nature, I Jan. 1S85, v. 31, p. 202); suggestion that the growing of lycopersicum escilentum would repel insects; comments on the inefficacr of the plant for such use.
$B . P . M .(428 \mathrm{I})$

[Tömösváry, Ödön (=Edmund).] [Luminosity of geophilus.] (Psyche, Oct.-Dec. I 884, v. 4, p. $235,5 \mathrm{~cm}$.)

Notice of article by $\ddot{O}$. Tömösváry in Rovarlani lapok, i $8 S_{4}$, v. I, p. $\mathrm{i} 7 \mathrm{I}$.

B: P. M. (42S2)

Townsend, C: H: Tyler. Calosomas and ricindelidac wanted. (Psyche, $1884, \mathrm{v} .4$, p. I78, I94, each $3 \mathrm{~cm}$.)

Advertisement.

B: P. M. (4283)

Townsend, C: H: Tyler. Notes on some coleoptera taken in south Louisiana. (Psyche, Oct.-Dec. I884, v. 4, p. 219-222, I $23 \mathrm{~cm}$.)

Sea-coast fauna of Louisiana considered a part of sub-tropical fauna of Mexico; notes on occurrence and habits of several colenptera of this fauna, and especially on the fulmination of brachynus tormentarius, on the driving of terrestrial species into trees and upon stumps by floods, on the protection of species by their habits or coloration, on sexual selection in desmocerus palliatus, on variations of rhodobaenus tredecimpunctatus, and on the odor of the latter species.
B: P. M. $(4284)$ 
[Trap-door spider nests.] (Psyche. May I 884, v. 4 , p. I $76,5 \mathrm{~cm}$.)

Reprint of "[C:teniza in California]" (Science, II Apr. 884 , v. 3, p. 469).

B: P. M. $\left(428_{5}\right)$

Trelease, W: Notes on the relations of two cecidomyians to fungi. (Psyche, Aug.Sep. 1884, v. 4, p. 195-200, I68 cm.)

Rev., by F. A. W. Thomas. (Irmischia, I 885 , v. 5, p. $4^{-}$.)

Abstract of Thomas' review, by H. A. Hagen, entitled "On the relations of fungi to galls and to larvae of cecidomyia living in galls." (Can. entom., July I885, v. 17, p. I36-137.) (Psyche, Oct.-I)ec, I88.5, v. 4, p. 334.)

Remarks on the occurrence of larvae of cecidomyia in sori of several named uredineae, and on the foodhabits of some other species of cecidomy of rhytisma asteris, $r$. solidaginis, and $r$. bifrons $(=$ ? $r$. asteris), on leaves of aster and solidago, the loci of these fungi being inhabited by larvae and described as the galls of cecidomyia carbonifera; fruit of the rhy. tisma unknown; interdependence of the fungi and insects.

$B: P . M .(42 S 6)$

Trimerous silphidae. (Psyche, Apr.-June I 885 , v. 4, p. 297-298, 5 cm.)

Notice of D : Sharp's "Descriptions of two ncw coleoptera sent by M. de Lacerda from Bahia" (Compt.rend. Soc. entom. Belg., 7 Feb. ISS5, p. $21-24)$.

$B: P . M .\left(42 S_{7}\right)$

[Trogoderma tarsale as a museum pest.] (Psyche, Mch.-Apr. 1883 , v. 4, p. 39, $3 \mathrm{~cm}$.)

Extract from [C: V. Riley's] "Trogoderma tarsale as a museum pest" (Amer. nat., Feb. IS8, v. 17, p. 199). $B: P . M .(42 S)$

Types of lepidoptera transferred to Cambridge. (Entom. amer., June 1885 , v. I, p. 54.) (Psyche, Apr.-June 1885, v. 4, p. $297,4 \mathrm{~cm}$.

Notice of transfer of the collection of lepidopterin of the Peabody museum to the Museum of comparative zoology; the collection contains types by A. S. Packard, jr., and H. K. Morrison.

B: P. M. (4289)

Wailly, Alfred. Lepidoptera. (Psyche, I $88_{3}$, v. 4 , p. 2, 22, 42, 62, 82, each 3 cm.) Advertisement.

B: P. M. (4290)

[Walker, James J.] [Pitcairn island insects.] (Psyche, Apr. 1884, v. 4, p. 164,7 cm.)

Notes, extracted from J. J. Walker's "Entomological collecting on a voyage in the Pacific" (Entom. mo. mag., Mch. 1884, v. 20, p. 222-225), on the fauna of Pitcairn island.

B: P. M. (4291)

[Walker, James J.] [Scavenger betles.] (Psyche, Oct.-Dec. I884, v. 4, p. 234. 4 cm.)

Notice of J. J. Walker's "Notes on dermestes vulpinus and other beetles in Sheppey" (Entom. mo. mag., Dec. i 884, v. 21, p. 16r).

B: P. M. $(4292)$
Waterhouse, C: O.] Specimens faded by exposure to light. (Amer. nat., Jan. 1885, v. I9, p. So.) (Psyche, Apr.-June 188.5 , v. 4 . p. 297,5 cm.)

Notice of communication made by $\mathrm{C}: \mathrm{O}$. Waterhouse to Entomological society of London, 2 July 1884 ; change of color produced in phytophagous coleoptera by long exposurt to light.

$B: P . M$. (4293)

What is involved in the production of a kilogram of honey (Psyche, Apr.-June I $88_{5}$, v. 4 , p. 299 , I 2 cm.)

Translated extract from Deutscher bienenfreund, Feb. I 885 , v. 2I, p. 50, with comments thereon by A. J: Cook and another; statistics of number of flowers of trifolium required to yield one kilogram of honey, and of amount of honey produced in one season. B: P.M. (4294)

Williston, S: Wendell. Collection and preservation of diptera. (Psyche, Jan.-Feb. IS84, v. 4, p. 130-132, 57 cm.)

Directions for hunting, capturing, killing and preserving diptera for the cabinet. $B: P . M$. (4295)

Williston, S: Wendell. Protective secretions of species of eleodes. (Psyche, May זSS4, v. 4, p. $168-169,32 \mathrm{~cm}$ )

Statement of the possession and method of defensive use of a mephitic secretion by certain species of eleodes; habits of the bectles.

$B: P . M .(4201)$

Williston, S: Wendell. The screw-worm fly, rompsomyia macellaria. (Psyche, Nov.-Dec. 1883 , v. 4 , p. I I 2-I I $4,70 \mathrm{~cm}$.)

Netice of F. II. Snow's "IIominivorous habits of lucilia macellaria"... (Psyche, Mch.-A pr. $188_{3}$, v. 4, p. 27-30) [Rec., 4272 ]; crit. rev. of J. M. F. Bigot's criticism on Snow's paper; abstrac $t$ of observations recorded by E. L. Arribálzilga (A nal. Snc. cient. argen. tina, v. Io, p. So-\$4) on habits and synonymy of comp. somyia macellaria: B: P. M. (4397)

[Wood-Mason, James.] [Tea insects of Assam.] (Science, 3r Oct. 1883, v. 4, p. 426. $7 \mathrm{~cm}$.) (Psyche, Oct.-Dec. $\mathrm{r} 884$, v. 4 , p. $235^{-23} 6$, ro $\mathrm{cm}$.)

Notice of report made by J. Wood-Mason on insects injuring thea in Assam; habits and ravages of the principal two insect enemies of this plant.

B: P. M. (429s)

Zoological society of London. (Psyche, Jul.-Aug. I 883 . v. 4 , p. 76, I $2 \mathrm{~cm}$.)

Partial abstract (from Zoologischer anzeiger, $\mathrm{I}_{3} 3$. v. 6) of communications made at meetings of Zoological socicty of London, ig Dec. 1882 and 5 June $188_{3}$.

$$
\text { B: P. M. (4299) }
$$

Zoological society of London. (Psyche, Jan.-Mch. 1885 , v. 4 , p. 253-254, I 8 cm.)

Partial abstract (from Zoologischer anzeiger) of minutes of meetings of Zoological society of London, ro June iss 3 -I Apr. rsS4.
B: P. M. (4300) 

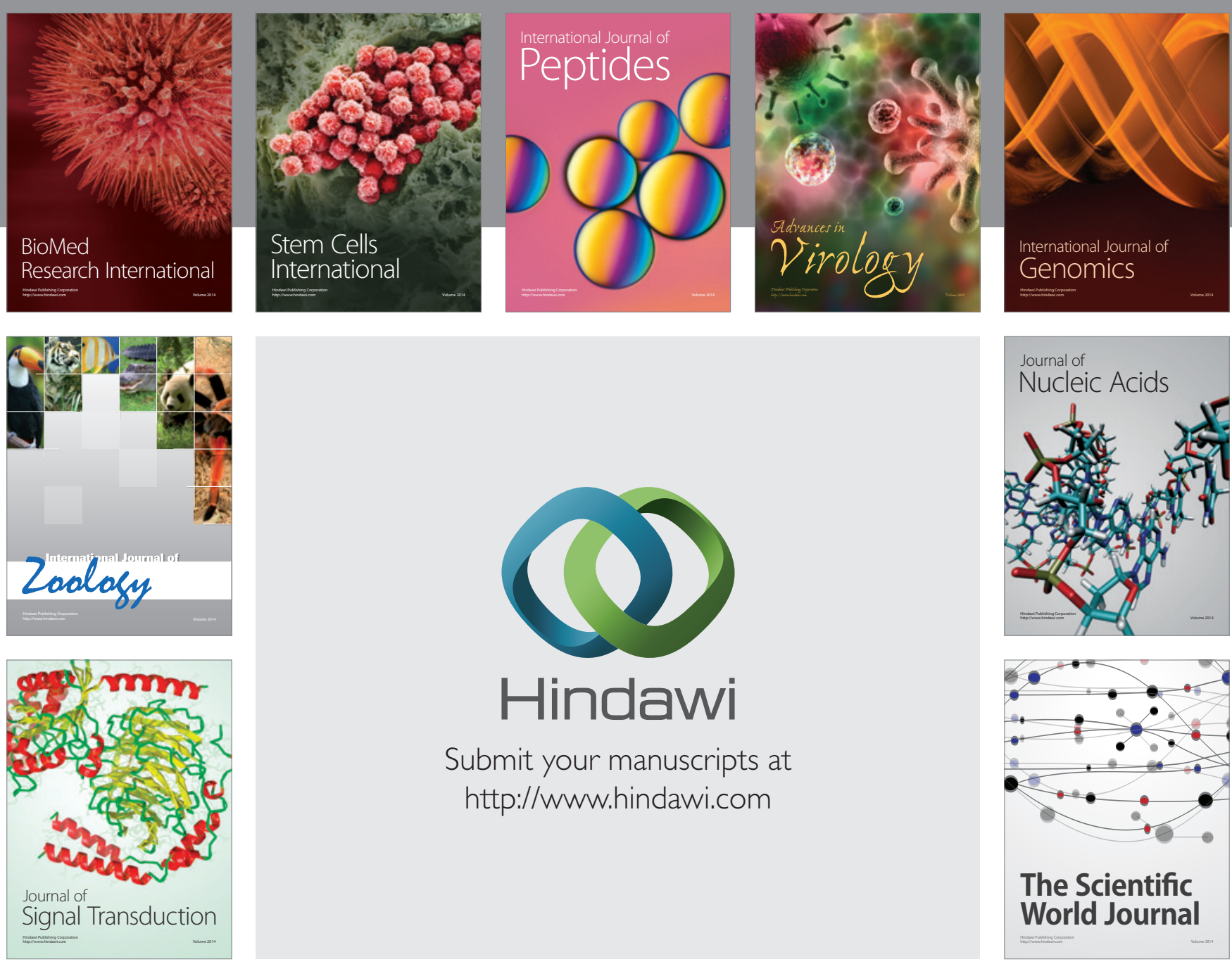

Submit your manuscripts at

http://www.hindawi.com
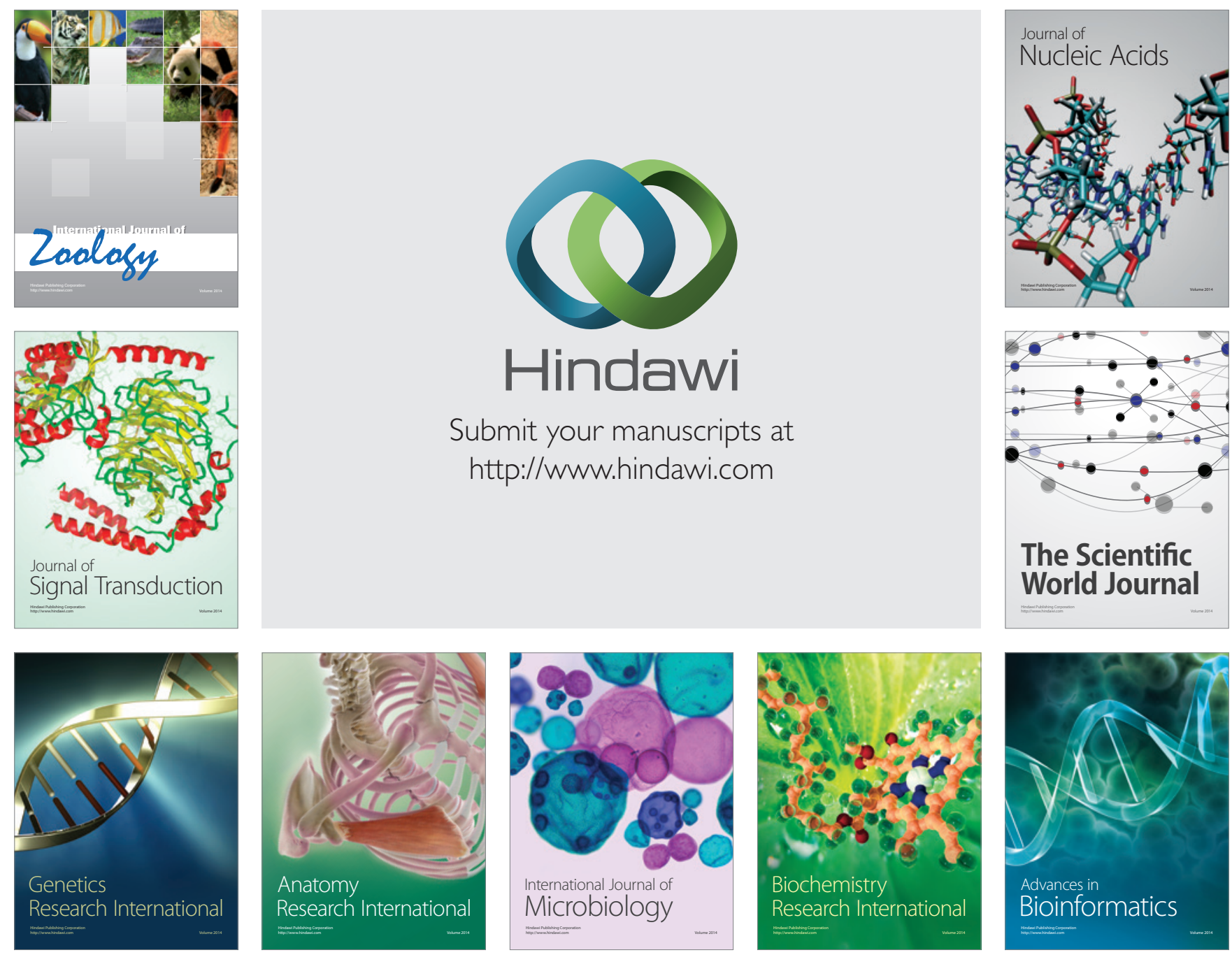

The Scientific World Journal
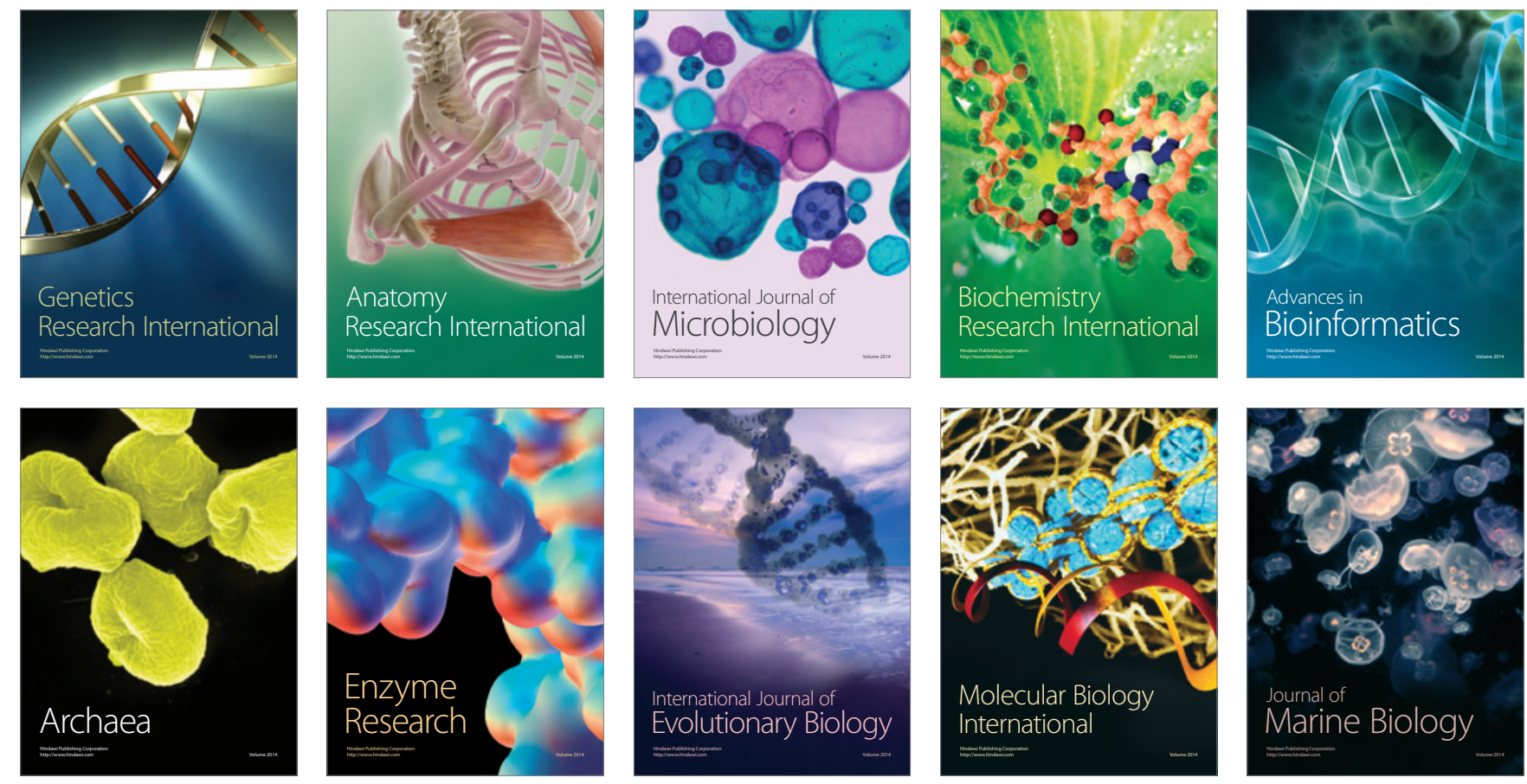